(RESEARCH ARTICLE)

\title{
Importance of phosphorus application in Acacia mangium plantation
}

\author{
Vu Tien Lam ${ }^{1}$, Nguyen Huy Son 2, Nguyen Toan Thang 1, Phung Dinh Trung 1, Pham Dinh Sam 1, Ho Trung \\ Luong ${ }^{1}$, Nguyen Huu Thinh ${ }^{1}$, Dao Trung Duc ${ }^{1}$ and Tran Van Do ${ }^{1, *}$
}

${ }^{1}$ Silviculture Research Institute, Vietnamese Academy of Forest Sciences, Hanoi, Vietnam.

2 Non-Timber Forest Products Research Centre, Vietnamese Academy of Forest Sciences, Hanoi, Vietnam.

Publication history: Received on 15 April 2019; revised on 11 May 2019; accepted on 14 May 2019

Article DOI: https://doi.org/10.30574/wjarr.2019.2.1.0028

\begin{abstract}
Fertilizers (nitrogen/N, phosphorous/P, and potassium/K) have been widely applied to increase the productivity of forest plantation, especially in poor soils. This study was to test the effects of fertilization at planting and additional fertilization in the following two years on growth and aboveground biomass (AGB) of a 30-month old plantation of Acacia mangium in Northeast Vietnam. There were four treatments including (1) $1 \mathrm{~kg}$ compost/tree at planting and 0.2 $\mathrm{kg}$ NPK (16:16:8)/tree/year in the following two years (IC-A-NPK), (2) $1 \mathrm{~kg}$ compost/tree at planting and $0.2 \mathrm{~kg} P$ $\left(16.5 \% \mathrm{P}_{2} \mathrm{O}_{5}\right)+0.1 \mathrm{~kg} \mathrm{~K}\left(60 \% \mathrm{~K}_{2} \mathrm{O}\right) /$ tree/year in the following two years (IC-A-PK), (3) $1 \mathrm{~kg}$ compost $+0.2 \mathrm{~kg} \mathrm{NPK} /$ tree at planting and $0.2 \mathrm{~kg} \mathrm{NPK} /$ tree/year in the following two years (IM-A-NPK), and (4) $1 \mathrm{~kg}$ compost $+0.2 \mathrm{~kg}$ NPK/tree at planting and $0.6 \mathrm{~kg} \mathrm{P}+0.1 \mathrm{~kg} \mathrm{~K} /$ tree/year in the following two years (IM-A-PK). The results indicated there was no significant effect of fertilization at planting and additional fertilization on diameter at breast height (DBH), basal area, and AGB between IC-A-NPK (DBH of $8.9 \mathrm{~cm}$, basal area of $7.4 \mathrm{~m}^{2} \mathrm{ha}^{-1}$, and AGB of $37.8 \mathrm{Mg} \mathrm{ha}^{-1}$ ) and IM-A-NPK (DBH of $10.1 \mathrm{~cm}$, basal area of $9.2 \mathrm{~m}^{2} \mathrm{ha}^{-1}$, and AGB of 47.5 $\left.\mathrm{Mg} \mathrm{ha}^{-1}\right)$. Meanwhile, DBH $(9.6 \mathrm{~cm})$, basal area $\left(8.6 \mathrm{~m}^{2} \mathrm{ha}^{-1}\right)$ and AGB (44.2 $\mathrm{Mg} \mathrm{ha}^{-1}$ ) in IM-A-PK were significantly higher than that in IC-A-PK (DBH of $8.4 \mathrm{~cm}$, basal area of $6.4 \mathrm{~m}^{2} \mathrm{ha}^{-1}$, and AGB of $31.6 \mathrm{Mg} \mathrm{h}^{-1}$ ). It was concluded that fertilization at planting of both compost and NPK is not required for $A$. mangium plantation. While additional fertilization of phosphorus should be applied for higher productivity.
\end{abstract}

Keywords: Aboveground biomass; Fertilization; Nitrogen; Phosphorus; Productivity

\section{Introduction}

The total area of forest plantations in the world was 54.3 million ha and it may reach 90 million ha by 2050 [1]. Because of soil erosion from rain and wind, and nutrition loss from harvesting planted trees, soil quality has decreased, leading to decreased productivity of plantations in the following rotations [2]. Fertilization has been applied for many species to increase their productivity around the world [3-5] and is known as a viable silvicultural option [6]. The macronutrients [7] including nitrogen $(\mathrm{N})$, phosphorus $(\mathrm{P})$, and potassium $(\mathrm{K})$ are the key limiting nutrients in many environments [8]. Fertilizers could be applied at and/or after planting annually [9] to support tree growth [10]. The main purpose of fertilization to any forest plantation is to supply nutrients to planted trees for improved growth [11] and higher survival rate [12]. Therefore, the expectation of growers is that planted trees can absorb as much applied fertilizer as possible [13].

Acacias are fast-growing tree species, which could meet the growing demands of pulpwood and timber. For optimum growth and development, planted trees require a large amount of nutrients [14]. N, P, and K play an important role in the growth and development of plants [15-17], especially when trees are planted in poor soil [18]. Knowledge on nutrient relations in acacia plantations is therefore imperative for the application of nutrient to maintain nutrient contents within limits that ensure the yield sustainability. In Vietnam, plantation of acacias is becoming increasingly important in contributing to the national economy and livelihood of million people in rural areas [19], when logging

\footnotetext{
${ }^{*}$ Corresponding author

E-mail address: dotranvan@hotmail.com
} 
Vu et al. / World Journal of Advanced Research and Reviews, 2019, 02(01), 007-012

timber from natural forest is prohibited. The objective of this study is to examine the effect of fertilization on Acacia mangium plantations in Northeast Vietnam.

\section{Material and methods}

\subsection{Study site}

This study was conducted at the Forest Experiment Station (FES), College of Agriculture and Forestry Northeast, located in Uong Bi City, Quang Ninh province, Vietnam. The Uong Bi City has monsoon climate conditions with an annual temperature of $22.2^{\circ} \mathrm{C}$ and air humidity of $81 \%$ [20]. There are four distinct seasons including spring (Feb-Apr), summer (May-Aug), autumn (Sep-Nov), and winter (Dec-Feb). Total annual precipitation is 1.600-2.200 mm with 153 annual rainy days.

The site for the experiment in this study locates on flat land with a slope of $<3^{\circ}$. The site was classified as bared land with some trees of pines and other shrubs which were shorter than $3 \mathrm{~m}$. It was cleared and burnt to prepare the site for planting A. mangium. The soil is classified as Ferralic Acrisol with a depth of 70-80 cm. Soil sample analysis indicated a $\mathrm{pH}$ of 3.7 , organic matter of $2.7 \%$, $\mathrm{N}$ of $0.18 \%$, $\mathrm{P}$ of $2.2 \mathrm{mg} \mathrm{P} \mathrm{P}_{2} \mathrm{O}_{5} / 100 \mathrm{~g}$ soil, $\mathrm{K}$ of $3.5 \mathrm{mg} \mathrm{K} 2 \mathrm{O} / 100 \mathrm{~g}$ soil.

\subsection{Experiment}

Four-month-old seedlings were used, which had a 3.7-3.8 mm stump diameter and were $0.57-0.59 \mathrm{~m}$ in height. The seedlings were produced from quality-controlled seeds imported from Australia. Planting holes were prepared with the sizes of $40 \times 40 \times 40 \mathrm{~cm}$. A. mangium trees were planted at a spacing of $3 \times 3 \mathrm{~m}$. There were two treatments of fertilization at planting including (1) $1 \mathrm{~kg}$ compost/tree named as IC and (2) $1 \mathrm{~kg}$ compost $+0.2 \mathrm{~kg} \mathrm{NPK} /$ tree (NPK with the rate of 16:16:8) named as IM.

Additional fertilizer was applied in June 2017 after planting one year and June 2018 after planting two years. The experiment was designed based on two treatments of fertilization at planting. In IC, there were two treatments of additional fertilization including (a) $0.2 \mathrm{~kg} \mathrm{NPK} /$ tree named as IC-A-NPK and (b) $0.2 \mathrm{~kg} \mathrm{P}\left(16.5 \% \mathrm{P}_{2} \mathrm{O}_{5}\right)+0.1 \mathrm{~kg} \mathrm{~K}(60 \%$ $\mathrm{K}_{2} \mathrm{O}$ ) /tree named as IC-A-PK. In IM, there were two treatments of additional fertilization including (c) $0.2 \mathrm{~kg} \mathrm{NPK} /$ tree named as IM-A-NPK and (d) $0.6 \mathrm{~kg} \mathrm{P}+0.1 \mathrm{~kg} \mathrm{~K} /$ tree named as IM-A-PK. Combination of both initial and additional fertilizations resulted four treatments including IC-A-NPK $(1 \mathrm{~kg}$ compost/tree at planting, $0.2 \mathrm{~kg} \mathrm{NPK} /$ tree in 2017, and $0.2 \mathrm{~kg} \mathrm{NPK} /$ tree in 2018), IC-A-PK (1 kg compost/tree at planting, $0.2 \mathrm{~kg} \mathrm{P}+0.1 \mathrm{~kg} \mathrm{~K} /$ tree in 2017, and $0.2 \mathrm{~kg} P+0.1$ $\mathrm{kg} \mathrm{K} /$ tree in 2018), IM-A-NPK ( $1 \mathrm{~kg}$ compost $+0.2 \mathrm{~kg} \mathrm{NPK} /$ tree at planting, $0.2 \mathrm{~kg}$ NPK/tree in 2017, and $0.2 \mathrm{~kg}$ NPK/tree in 2018), and IM-A-PK (1 kg compost $+0.2 \mathrm{~kg} \mathrm{NPK} /$ tree at planting, $0.6 \mathrm{~kg} \mathrm{P}+0.1 \mathrm{~kg} \mathrm{~K} /$ tree in 2017, and $0.6 \mathrm{~kg} \mathrm{P}+0.1$ $\mathrm{kg} \mathrm{K} /$ tree in 2018).

Each treatment was designed in a plot of 32 trees ( 8 lines $\times 4$ trees/line). For additional fertilizing, four holes of $20 \times 20$ $\times 10 \mathrm{~cm}$ (width $\times$ length $\times$ depth) on the soil surface, which were $50-70 \mathrm{~cm}$ from the stem of $A$. mangium trees, were made and mix of both fertilizers was distributed equally. Holes were then covered by fine soil.

\subsection{Data Collection and Analysis}

Diameter at breast height (DBH in $\mathrm{cm}$ ) of all stems in plots was measured at 3-month intervals including December 2017 (Dec-17), March 2018 (Mar-18), June 2018 (Jun-18), September 2018 (Sep-18), and December 2018 (Dec-18). Aboveground biomass (AGB) of each stem was estimated based on DBH using the equation: AGB $=0.223^{*} \mathrm{DBH}^{2.251}$ [21]. In additional, the basal area of each stem was also estimated. The AGB and basal area were transferred to the unit of Mg $\mathrm{ha}^{-1}$ and $\mathrm{m}^{2} \mathrm{ha}^{-1}$, respectively.

Comparison between treatments was conducted by pair-comparison. SAS 9.2 was employed for statistical analysis

\section{Results}

In IC-A-NPK and IM-A-NPK treatments (Table 1), there was only a difference in types and amount of fertilizer applied at planting. While there was the same amount of NPK applied in both 2017 and 2018. In term of DBH, there were significant differences only for data measured in Dec-17 and Mar-18. While the differences in other dates were not found (Table 1). The differences of both basal area and AGB between IC-A-NPK and IM-A-NPK were not found at any times. In December 2018 after planting 30 months, the plantation in IC-A-NPK treatment achieved $8.9 \mathrm{~cm} \mathrm{DBH,} 7.4 \mathrm{~m}^{2} \mathrm{ha}^{-1}$ basal 
Vu et al. / World Journal of Advanced Research and Reviews, 2019, 02(01), 007-012

area, and 37.8 $\mathrm{Mg} \mathrm{ha}^{-1} \mathrm{AGB}$ (Table 1). While plantation in IM-A-NPK treatment achieved $10.1 \mathrm{~cm} \mathrm{DBH}^{9} 9.2 \mathrm{~m}^{2} \mathrm{ha}-1 \mathrm{basal}^{-}$ area, and 47.5 $\mathrm{Mg} \mathrm{ha}^{-1} \mathrm{AGB}$

Table 1 Effects of initial fertilization on DBH, basal area, and AGB of $A$. mangium plantations (mean \pm SE)

\begin{tabular}{|c|c|c|c|c|c|c|c|}
\hline $\begin{array}{l}\text { Treatment } \\
\text { code }\end{array}$ & $\begin{array}{l}\text { Fertilization at planting } \\
\left(\text { tree }^{-1}\right)\end{array}$ & $\begin{array}{l}\text { Additional } \\
\text { fertilization } \\
\left(\text { tree }^{-1}\right)\end{array}$ & Dec-17 & Mar-18 & $\begin{array}{l}\text { DBH (cm) } \\
\text { Jun-18 }\end{array}$ & Sep-18 & Dec-18 \\
\hline IC-A-NPK & $1 \mathrm{~kg}$ compost & $0.2 \mathrm{~kg} \mathrm{NPK}$ & $6.0 \pm 0.61^{\mathrm{a}}$ & $6.6 \pm 0.59 \mathrm{a}$ & $7.2 \pm 0.62$ & $8.4 \pm 0.74$ & $8.9 \pm 0.79$ \\
\hline \multirow[t]{2}{*}{ IM-A-NPK } & $1 \mathrm{~kg}$ compost $+0.2 \mathrm{~kg}$ NPK & $0.2 \mathrm{~kg} \mathrm{NPK}$ & $7.0 \pm 0.29 b$ & $7.5 \pm 0.31^{b}$ & $8.0 \pm 0.35$ & $9.5 \pm 0.48$ & $10.1 \pm 0.75$ \\
\hline & & & \multicolumn{5}{|c|}{ Basal area $\left(\mathrm{m}^{2} \mathrm{ha}^{-1}\right)$} \\
\hline IC-A-NPK & $1 \mathrm{~kg}$ compost & $0.2 \mathrm{~kg} \mathrm{NPK}$ & $3.5 \pm 0.52$ & $4.1 \pm 0.57$ & $4.9 \pm 0.66$ & $6.7 \pm 0.91$ & $7.4 \pm 1.10$ \\
\hline \multirow[t]{2}{*}{ IM-A-NPK } & $1 \mathrm{~kg}$ compost $+0.2 \mathrm{~kg} \mathrm{NPK}$ & $0.2 \mathrm{~kg} \mathrm{NPK}$ & $4.4 \pm 0.35$ & $5.0 \pm 0.39$ & $5.7 \pm 0.47$ & $8.0 \pm 0.75$ & $9.2 \pm 0.94$ \\
\hline & & & \multicolumn{5}{|c|}{ AGB (Mg ha-1) } \\
\hline IC-A-NPK & $1 \mathrm{~kg}$ compost & $0.2 \mathrm{~kg} \mathrm{NPK}$ & $16.2 \pm 2.6$ & $19.5 \pm 2.9$ & $23.5 \pm 3.4$ & $33.6 \pm 4.9$ & $37.8 \pm 5.5$ \\
\hline IM-A-NPK & $1 \mathrm{~kg}$ compost $+0.2 \mathrm{~kg} \mathrm{NPK}$ & $0.2 \mathrm{~kg} \mathrm{NPK}$ & $20.6 \pm 1.8$ & $23.9 \pm 2.1$ & $27.7 \pm 2.5$ & $40.7 \pm 4.2$ & $47.5 \pm 5.4$ \\
\hline
\end{tabular}

Additional fertilization = fertilization in 2017 and 2018 at one and two years after planting, respectively. Different letters ${ }^{\mathrm{a}} \mathrm{b}$ in a column indicate a significant difference of means by $t$-test at $p=0.05$

In IC-A-PK and IM-A-PK treatments (Table 2), there were differences in both fertilization at planting and additional fertilization. Pair-comparison indicated that the differences of DBH, basal area, and AGB between two treatments were significant in all collected dates. The results indicated better plantation in IM-A-PK treatment than that in IC-A-PK treatment (Table 2). In December 2018 after planting 30 months, the plantation in IC-A-PK treatment achieved $8.4 \mathrm{~cm}$ DBH, $6.4 \mathrm{~m}^{2} \mathrm{ha}^{-1}$ basal area, and $31.6 \mathrm{Mg} \mathrm{ha}^{-1} \mathrm{AGB}$ (Table 2). While plantation in IM-A-PK treatment achieved $9.6 \mathrm{~cm}$ DBH, $8.6 \mathrm{~m}^{2} \mathrm{ha}^{-1}$ basal area, and 44.2 $\mathrm{Mg} \mathrm{ha}^{-1} \mathrm{AGB}$

Table 2 Effects of both initial and additional fertilizations on DBH, basal area, and AGB of A. mangium plantations (mean $\pm \mathrm{SE}$ )

\begin{tabular}{|c|c|c|c|c|c|c|c|}
\hline \multirow{2}{*}{$\begin{array}{l}\text { Treatment } \\
\text { code }\end{array}$} & \multirow{2}{*}{$\begin{array}{l}\text { Fertilization } \\
\text { at planting } \\
\left(\text { tree }^{-1}\right)\end{array}$} & \multirow{2}{*}{$\begin{array}{l}\text { Additional } \\
\text { fertilization } \\
\text { (tree-1) }\end{array}$} & \multicolumn{5}{|c|}{ DBH $(\mathrm{cm})$} \\
\hline & & & Dec-17 & Mar-18 & Jun-18 & Sep-18 & Dec-18 \\
\hline IC-A-PK & $1 \mathrm{~kg}$ compost & $0.2 \mathrm{~kg} P+0.1 \mathrm{~kg} \mathrm{~K}$ & $5.7 \pm 0.36^{\mathrm{a}}$ & $6.3 \pm 0.39 a$ & $6.8 \pm 0.41^{\mathrm{a}}$ & $8.1 \pm 0.40^{\mathrm{a}}$ & $8.4 \pm 0.48^{a}$ \\
\hline IM-A-PK & $\begin{array}{l}1 \mathrm{~kg} \text { compost } \\
+0.2 \mathrm{~kg} \mathrm{NPK}\end{array}$ & $0.6 \mathrm{~kg} P+0.1 \mathrm{~kg} \mathrm{~K}$ & $6.8 \pm 0.62^{b}$ & $7.5 \pm 0.57 \mathrm{~b}$ & $7.9 \pm 0.63^{b}$ & $9.2 \pm 0.73^{b}$ & $9.6 \pm 0.78^{b}$ \\
\hline
\end{tabular}

\begin{tabular}{|c|c|c|c|c|c|c|c|}
\hline \multirow[b]{2}{*}{ IC-A-PK } & \multirow[b]{2}{*}{$1 \mathrm{~kg}$ compost } & \multirow[b]{2}{*}{$0.2 \mathrm{~kg} P+0.1 \mathrm{~kg} \mathrm{~K}$} & \multicolumn{5}{|c|}{ Basal area $\left(\mathrm{m}^{2} \mathrm{ha}^{-1}\right)$} \\
\hline & & & $3.0 \pm 0.33^{\mathrm{a}}$ & $3.6 \pm 0.39 \mathrm{a}$ & $4.2 \pm 0.45^{a}$ & $5.8 \pm 0.55^{a}$ & $6.4 \pm 0.61^{a}$ \\
\hline \multirow[t]{2}{*}{ IM-A-PK } & $\begin{array}{l}1 \mathrm{~kg} \text { compost } \\
+0.2 \mathrm{~kg} \text { NPK }\end{array}$ & $0.6 \mathrm{~kg} P+0.1 \mathrm{~kg} \mathrm{~K}$ & $4.3 \pm 0.59 \mathrm{~b}$ & $5.1 \pm 0.58^{b}$ & $5.8 \pm 0.69^{b}$ & $7.8 \pm 0.91^{b}$ & $8.6 \pm 1.01^{b}$ \\
\hline & & & \multicolumn{5}{|c|}{ AGB (Mg ha-1) } \\
\hline IC-A-PK & $1 \mathrm{~kg}$ compost & $0.2 \mathrm{~kg} P+0.1 \mathrm{~kg} \mathrm{~K}$ & $13.5 \pm 1.6^{\mathrm{a}}$ & $16.6 \pm 2.0^{\mathrm{a}}$ & $19.9 \pm 2.3^{\mathrm{a}}$ & $28.5 \pm 2.9^{a}$ & $31.6 \pm 3.3^{a}$ \\
\hline IM-A-PK & $\begin{array}{l}1 \mathrm{~kg} \text { compost } \\
+0.2 \mathrm{~kg} \mathrm{NPK}\end{array}$ & $0.6 \mathrm{~kg} P+0.1 \mathrm{~kg} \mathrm{~K}$ & $20.7 \pm 3.0^{\mathrm{b}}$ & $24.8 \pm 3.0^{\mathrm{b}}$ & $28.8 \pm 3.6^{b}$ & $39.6 \pm 4.9^{b}$ & $44.2 \pm 5.6^{b}$ \\
\hline
\end{tabular}

There were two additional fertilization treatments in IC (fertilization at planting of $1 \mathrm{~kg}$ compost/tree). Pair-comparison indicated that the effect of additional fertilization on DBH, basal area, and AGB was not significant. Even the figures in the treatment of additional fertilization of $0.2 \mathrm{~kg} \mathrm{NPK} /$ tree were higher than that in treatment of $0.2 \mathrm{~kg} \mathrm{P}+0.1 \mathrm{~K} \mathrm{~kg} / \mathrm{tree}$ (Fig. 1). 

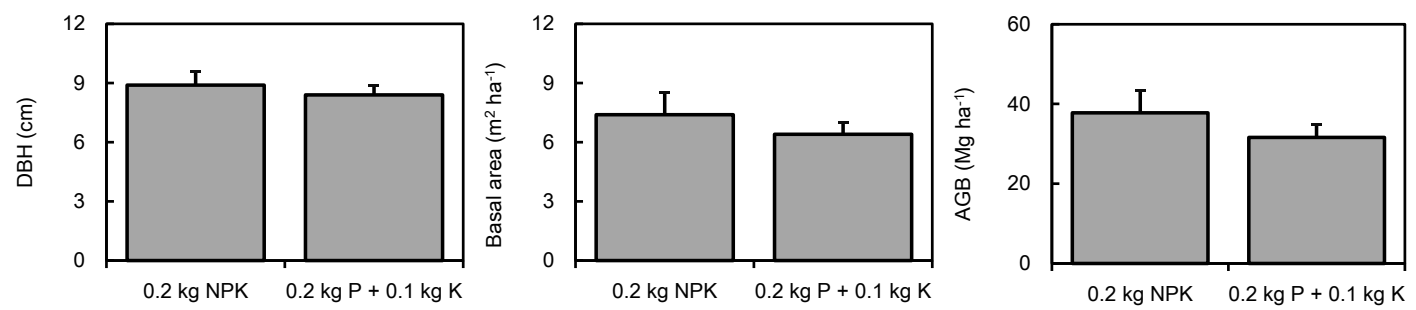

Figure 1 Effects of additional fertilization on DBH, basal area, and AGB of 30-month old A. mangium plantation in treatment of fertilization at planting of $1 \mathrm{~kg}$ compost/tree. Bars indicate +SE. Additional fertilizer was applied twice in Junes 2017 and 2018

There were two additional fertilization treatments in IM (fertilization at planting of $1 \mathrm{~kg}$ compost $+0.2 \mathrm{~kg} \mathrm{NPK} /$ tree). Pair-comparison indicated that the effect of additional fertilization on DBH, basal area, and AGB was also not significant. Even the figures in the treatment of additional fertilization of $0.2 \mathrm{~kg} \mathrm{NPK} /$ tree were slightly higher than that in treatment of $0.6 \mathrm{~kg} \mathrm{P}+0.1 \mathrm{~kg} \mathrm{~K} /$ tree (Fig. 2).
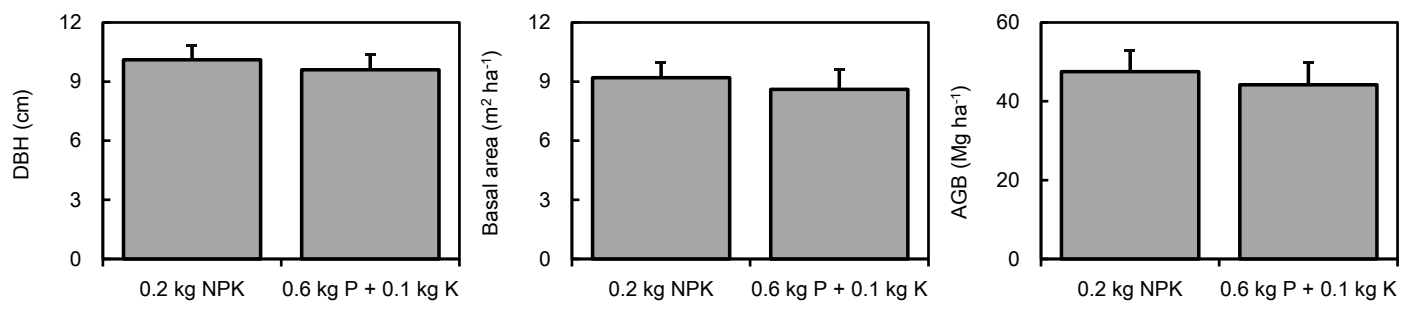

Figure 2 Effects of additional fertilization on DBH, basal area, and AGB of 30-month old A. mangium plantation in treatment of fertilization at planting of $1 \mathrm{~kg}$ compost $+0.2 \mathrm{~kg} \mathrm{NPK} /$ tree. Bars indicate + SE. Additional fertilizer was applied twice in Junes 2017 and 2018

\section{Discussion}

The response of plantations to fertilization depends on the degree of mismatch of nutrient supply [22, 23]. Responses in nutrient-poor soil are stronger than nutrient-rich soil. There was no significant effect of fertilization at planting on DBH (Table 1). Seedlings at planting were small and they were planted in the early rainy season, therefore they could not absorb all applied fertilizer. Of which, NPK is easily lost through leaching, erosion, and uptake by other vegetation in the rainy season. However, DBH, basal area, and AGB in treatment of $1 \mathrm{~kg}$ compost $+0.2 \mathrm{~kg}$ NPK/tree (IM-A-NPK) were slightly higher than that in treatment of $1 \mathrm{~kg}$ compost/tree (IC-A-NPK) (Table 1). This indicated the effect of NPK application on A. mangium plantation. As NPK is soluble and is easily uptake immediately by planted trees.

Additional fertilization in 2017 and 2018 of $0.6 \mathrm{~kg} \mathrm{P}+0.1 \mathrm{~kg} \mathrm{~K} /$ tree/year resulted in significant higher DBH, basal area, and AGB at any collected dates than that in application of $0.2 \mathrm{~kg} \mathrm{P}+0.1 \mathrm{~kg} \mathrm{~K} /$ tree (Table 2). This indicated the importance of $\mathrm{P}$ to support the growth of acacia plantation. Legumes such as acacias would have a particularly high demand for $\mathrm{P}$, as they are thought to have enough $\mathrm{N}$ due to their $\mathrm{N}$-fixing ability [24]. A. mangium stands can fix more than $30 \mathrm{~kg} \mathrm{~N} / \mathrm{ha} /$ year [25], which will be returned to the soil through litter decomposition. Therefore, A. mangium plantation demands higher supply of P.

Water holding capacity of compost is high, while nutrient content is low and not ready soluble like NPK. Therefore, applying in June/rainy season may not maximize its function for planted trees. Compost should be applied in the late rainy season and/or in spring to support water holding for planted trees. In addition, compost should be applied in nutrient-medium and dry soil to both holding water and releasing nutrient gradually for planted tree's uptake. While NPK should be applied in poor soil to support immediate uptake.

In medium-fertile soil, fertilization at planting is not required as small-sized planted trees could not fully uptake applied fertilizer leading to higher loss. While in poor-fertile soil fertilizer should be applied to support initial growth and higher survival rate of plantation [12]. Fertilization timing is also important. If applying in high rainfall time, rate of fertilizer loss will be high through leaching and soil erosion. Therefore, it should be applied in low rainfall time, then planted trees can uptake gradually by their capacity and needs. 


\section{Conclusion}

Acacia plantations have remarkably contributed to poverty reduction in Vietnam. To increase productivity, fertilizers have been widely applied. This research indicated that applying $1 \mathrm{~kg}$ compost $+0.2 \mathrm{~kg} \mathrm{NPK} /$ tree at planting and additional fertilization of $0.6 \mathrm{~kg} \mathrm{P}+0.1 \mathrm{~kg} \mathrm{~K} /$ tree/year in the two following years to A. mangium plantation of 1,330 trees ha-1 resulted in average DBH of $9.6 \mathrm{~cm}$ and AGB of $44.2 \mathrm{Mg} \mathrm{ha}^{-1}$ at 30 months old. Meanwhile, it could achieve average DBH of $10.1 \mathrm{~cm}$ and AGB of $47.5 \mathrm{Mg} \mathrm{ha}^{-1}$ if applying $1 \mathrm{~kg}$ compost $+0.2 \mathrm{~kg} \mathrm{NPK} /$ tree at planting and additional fertilization of $0.2 \mathrm{~kg} \mathrm{NPK} /$ tree/year in the two following years.

Fertilization at planting should not be applied as it did not significantly effect on growth and AGB of A. mangium plantation. Since small-sized planted trees could not fully absorb applied fertilizer leading to its loss uneconomically. Compost should be applied in nutrient-medium and dry soil for both holding water and releasing nutrient gradually, and NPK should be applied in poor soil.

\section{Compliance with ethical standards}

\section{Acknowledgments}

This research is funded by Vietnam National Foundation for Science and Technology Development (NAFOSTED) under grant number 106-NN.06-2016.10. We would like to thank anonymous reviewers for constructive comments on the manuscript.

\section{Disclosure of conflict of interest}

Authors have declared that no competing interests exist.

\section{Statement of ethical approval}

Ethical approval was obtained from Silviculture Research Institute, Vietnamese Academy of Forest Sciences, Hanoi, Vietnam.

\section{References}

[1] Indufor (2012). A12-06869 Strategic review on the future of forest plantation (ID 11914). Forest Stewardship Council, Helsinki Finland.

[2] Zech W and Drechsel P. (1995). Degradation and amelioration of soils and tree nutrient status without and with mineral fertilizer. In: Schulte, A. and Ruhiyat, D. (eds.) Soils of tropical forest ecosystems 5, 5-30. Mulawarman University Press, Samarinda, Indonesia.

[3] Timander P. (2011). Fertilization in Eucalyptus urophylla plantations in Guangxi, southern China. Master thesis, Southern Swedish Forest Research Centre, Swedish University of Agricultural Sciences.

[4] Mello EASC, Gonçalves JLM, Rocha JHT, Hakamada RE, Bazani JH, Wenzel AVA, Junior JCA, Borges JS, Malheiros R, Lemos CCZ, Ferreira EVO and Ferraz AV. (2016). Responses of clonal eucalypt plantations to N, P and K fertilizer application in different edaphoclimatic conditions. Forests, 7, 2.

[5] Moya JF, Alvarado A, Ayanz ASM and Sacristan MM. (2014). Forest nutrition and fertilization in teak (Tectona grandis L.f.) plantations in Central America. New Zealand Journal of Forest Science, 44, S6.

[6] Fox TR, Allen HL, Albaugh TJ, Rubilar R and Carlson CA. (2007). Tree nutrition and forest fertilization of pine plantations in the Southern United States. Southern Journal of Applied Forestry, 31, 5-11.

[7] Sulaiman A, Kadir QRA and Midon MS. (1990). Effects of fertilizer on wood properties of plantation crown Acacia mangium. Journal of Tropical Forest Science, 4, 119-126.

[8] Goncalves JLM, Wichert MCP, Gava JL, Masetto AV, Arthur JCJ, Serrano and Mello SLM. (2007). Soil fertility and growth of Eucalyptus grandis in Brazil under different residue management practices. Southern Hemisphere Forestry Journal, 69, 95-102.

[9] Guo J, Wu Y, Wang B, Lu Y, Cao F and Wang G. (2016) The effects of fertilization on the growth and physiological characteristics of Ginkgo biloba L. Forests, 7, 293. 
[10] Lamani VK, Patil SK and Manjunath GO. (2004). Growth of Acacia auriculiformis as influenced by N, P and K fertilizers. Karnataka Journal of Agriculture Science, 17, 872-874.

[11] Forrester DI, Collopy JJ, Beadle CL, Warren CR and Baker TG. (2012). Effect of thinning, pruning and nitrogen fertilizer application on transpiration, photosynthesis and water-use efficiency in a young Eucalyptus nitens plantation. Forest Ecology and Management, 266, 286-300.

[12] Earnshaw KM, Baribault TW and Jacobs DF. (2016). Alternative field fertilization techniques to promote restoration of leguminous Acacia koa on contrasting tropical sites. Forest Ecology and Management, 376, 126134.

[13] Silva PHM, Poggiani F, Libardi PL and Gonçalves AN. (2013). Fertilizer management of eucalypt plantations on sandy soil in Brazil: Initial growth and nutrient cycling. Forest Ecology and Management, 301, 67-78.

[14] Evans J. (1992). Plantation Forestry in the Tropics. Clarendes Press, Oxford.250-255.

[15] Ralston CW. (1978). Mineral cycling in temperate forest ecosystem. Forest Soils and Land Use. 320-324.

[16] Koul VK, Bhardwaj SD and Kaushal AN. (1995). Effect of N and P application on nutrient uptake and biomass production in Bauhinia variegata Linn seedlings. Indian Forester, 121, 14-22.

[17] aman VK, Patil SK and Manjunath GO. (2004). Growth of Acacia auriculiformis as influenced by N, P and K fertilizers. Karnataka Journal Agriculture Science, 17, 872-874.

[18] Leite FP, Barros NF, Novais RF and Fabres AS. (1998). Accumulation and distribution of nutrients in Eucalyptus grandis under different population densities. Brazilian Journal of Soil Science, 22, 419-426.

[19] Kien ND, Thinh HH, Kha LD, Nghia NH, Hai PH and Hung TV. (2014). Acacia as a national resource of Vietnam. In: 'Sustaining the Future of Acacia Plantation Forestry' International Conference, IUFRO Working Party 2.08.07: Genetics and Silviculture of Acacia, Hue, Vietnam. Compendium of Abstracts.

[20] QCVN02. (2009) Vietnam Building Code Natural Physical \& Climatic Data for Construction. Hanoi. 324

[21] Thanh TX and Thu DH. (2015). Study on carbon accumulation capacity of the Acacia mangium plantation in Ngoc Thanh commune, Phuc Yen district, Vinh Phuc province, Vietnam. Proceeding of National Scientific Conference on Ecological and Biological Resources, 6, 1660-1666.

[22] Bennett LT, Weston CJ and Attiwill PM. (1997). Biomass, nutrient content and growth response to fertilizers of 6-year-old Eucalyptus globulus plantations at three contrasting sites in Gippsland. Australian Journal of Botany, 45, 103-121.

[23] Smethurst P, Baillie C, Cherry M and Holz G. (2003). Fertilizer effects on LIA and growth of four Eucalyptus nitens plantations. Forest Ecology and Management, 176, 531-542.

[24] Inagaki M, Inagaki Y, Kamo K and Titin J. (2009). Fine-root production in response to nutrient application at three forest plantations in Sabah, Malaysia: higher nitrogen and phosphorus demand by Acacia mangium. Journal of Forestry Research, 14, 178-182.

[25] Bouillet JP, Laclau JP, Gonçalves JLM, Moreira MZ, Trivelin PCO, Jourdan C, Silva EV, Piccolo MC, Tsai SM and Galiana A. (2008). Mixed-species plantations of Acacia mangium and Eucalyptus grandis in Brazil, II: nitrogen accumulation in the stands and biological N2 fixation. Forest Ecology and Management, 255, 3918-3930.

\section{How to cite this article}

Vu TL, Nguyen HS, Nguyen TT, Phung DT, Pham DS, Ho TL, Nguyen HT, Dao TD and Tran VD. (2019). Importance of phosphorus application in Acacia mangium plantation. World Journal of Advanced Research and Reviews, 2(1), 07-12. 